\title{
Pentingnya Pendidikan Karakter bagi Anak Usia Dini
}

\author{
Sudaryanti \\ Krysna2803@gmail.com \\ Universitas Negeri Yogyakarta
}

\begin{abstract}
Abstrak
Pendidikan karakter mempunyai makna lebih tinggi dari pendidikan moral karena bukan sekedar mengajarkan mana yang benar dan mana yang salah, tetapi membantu anak-anak merasakan nilai-nilai yang baik, mau dan mampu melakukannya. Pembentukan karakter pribadi anak (character building) sebaiknya dimulai dalam keluarga karena interaksi pertama anak terjadi dalam lingkungan keluarga. Pendidikan karakter sebaiknya di terapkan sejak anak usia dini karena pada usia dini karena sangat menentukan kemampuan anak dalam mengembangkan potensinya. Pendidikan karakter pada anak usia dini dapat mengantarkan anak pada matang dalam mengolah emosi. Kecerdasan emosi adalah bekal penting dalam mempersiapkan anak usia dini dalam menyongsong masa depan yang penuh dengan tantangan, baik secara akademis maupun dalam kehidupan berbangsa dan bernegara.
\end{abstract}

Kata kunci: Pendidikan Karakter, Pendidikan Anak Usia Dini

\begin{abstract}
Character education has a higher meaning of moral education because it is not only teaching what is right and what is wrong but also helping children feel the good values, has willingness and ability to do so. The establishment of children's personal character (character buildings) should start from the family as the children's first interaction occurs within the family. Character education should be implemented since early childhood because it determines the children's ability to develop their potentials. Character education in early childhood can lead children to be mature in processing their emotions. Emotional intelligence is an important provision in preparing early childhood to face future challenges, both in academic life and their life as citizen.
\end{abstract}

Keywords: character education, early childhood education

\section{Pendahuluan}

Menurut undang-undang No.20 pasal 1 butir 14 tahun 2003 tentang Pendidikan Anak Usia Dini (PAUD) adalah suatu upaya pembinaan yang ditujukan kepada anak sejak lahir sam- pai dengan usia 6 tahun yang dilakukan melalui pemberian rangsangan pendidikan untuk membantu pertumbuhan dan perkembangan jasmani dan rohani agar anak memiliki kesiapan dalam memasuki pendidikan lebih la- 
njut. Undang-undang No.20 tahun 2003 pasal 9 ayat 1 menegaskan setiap anak berhak memperoleh pendidikan dan pengajaran dalam rangka pengembangan pribadinya dan tingkat kecerdasannya sesuai minat dan bakatnya. Alasan pentingnya PAUD adalah: 1) anak usia dini adalah masa peka yang memiliki perkembangan fisik, motorik, intelektual dan sosial sangat pesat, 2) tingkat variabelitas kecerdasan orang dewasa, 50\%sudah terjadi ketika masa usia dini (4 tahun pertama), 30\% berikutnya pada usia 8 tahun dan $20 \%$ setelah mencapai usia 18 tahun, 3) anak usia dini berada pada masa pembentukan landasan awal bagi tumbuh dan kembang anak.

Pendidikan anak usia dini (PAUD) sangat penting dilaksanakan sebagai dasar bagi pembentukan kepribadian manusia secara utuh, yaitu untuk pembentukan karakter, budi pekerti luhur, cerdas, ceria, terampil, dan bertakwa kepada Tuhan Yang Maha Esa. Pendidikan anak usia dini dapat dimulai dari rumah atau dalam pendidikan keluarga. Berdasarkan undangundang di atas maka pendidikan karakter sangatlah penting untuk membangun beradaban bangsa, pendidikan karakter tersebut seharusnya sudah di tanamkan sejak anak usia dini sehingga mereka sangat tepat jika di jadikan komunitas awal pembentukan karakter karena anak berada pada usia emas (golden age).

Pembentukan karakter pribadi anak (character building) sebaiknya dimulai dalam keluarga karena anak mulai berinteraksi dengan orang lain pertama kali terjadi dalam lingkungan keluarga. Pendidikan karakter sebaiknya di terapkan sejak anak usia dini karena pada usia dini terbukti sangat menentukan kemampuan anak dalam mengembangkan potensinya. Sedangkan sekolah adalah salah satu lembaga yang bertanggung jawab terhadap pembentukan karakter, karena kontribusi dan peran guru disini sangat domi- nan. Tujuan utama pendidikan adalah menghasilkan kepribadian manusia yang matang secara intelektual, emosional, dan spiritual. Sekolah sebagai lembaga memiliki tanggung jawab moral untuk mendidik anak menjadi pintar dan cerdas sesuai dengan harapan orang tua dan masyarakat. Peran guru sangat strategis dalam pembentukan pribadi anak karena tugas guru tidak hanya mengajar tetapi juga mendidik. Tugas guru sebagai pendidik adalah membantu anak mendapatkan pengetahuan yang bermanfaat bagi anak dan masyarakat juga memiliki karakter dan kepribadian yang baik yang sesuai dengan tujuan pendidikan yaitu mengembangkan potensi peserta didik untuk memiliki kecerdasan, kepribadian, dan akhlak mulia(Undang-Undang Sisdiknas tahun 2003).

Kehidupan manusia sejak dalam kandungan sampai lahir kedunia ini melewati beberapa tahapan untuk bisa tumbuh dan berkembang. Masing-masing tahapan perkembangan mempunyai tugas dan fungsi serta peran yang berbeda. Masa kanak-kanak sangat tergantung pada orang dewasa, terutama pada masa awal kanak-kanak yaitu masa bayi. Begitu juga perkembangan moral anak berjalan seiring dengan perkembangan intelektual, emosional, bahasa dan sosial.

Pembentukan perilaku moral anak di lakukan melalui pendidikan di dalam keluarga, pembelajaran di masyarakat, pembimbingan baik di keluarga maupun di masyarakat, serta pendisiplinan anak mulai dari lingkungan keluarga. Pembentukan karakter (character building) dapat di lakukan melalui pendidikan budi pekerti yaitu melibatkan aspek pengetahuan (cognitif), perasaan (feeling), dan tindakan (action). Pendidikan karakter akan lebih efektif apabila melewati ketiga kegiatan tersebut.

Efek adanya pendidikan karakter pada anak usia dini akan menyebabkan anak usia dini akan matang dalam 
mengolah emosinya. Kecerdasan emosi adalah bekal terpenting dalam mempersiapkan anak usia dini dalam menyongsong masa depan yang penuh dengan tantangan baik secara akademis maupun dalam kehidupan berbangsa dan bernegara. Tujuan adanya modernisasi dan perkembangan teknologi menyebabkan perubahan sosial dalam kehidupan masyarakat, hal ini juga mempengaruhi kehidupan Anak Usia Dini. Dampak positif dalam pembelajaran dapat kita rasakan, Anak Usia Dini sudah sangat akrab dengan penggunaan hand phone untuk berkomunikasi. Penggunaan komputer untuk menggambar dan bermain game.

Dampak positif juga diikuti dampak negatif; di antaranya anak kalau sudah bermain game lupa waktu kalau tidak di ingatkan atau dikontrol orang tua. Anak-anak TK kebanyakan lebih suka melihat acara TV (televisi), yang kadang-kadang acaranya tidak mendidik, sehingga kebiasaan ini tentu kurang baik untuk generasi muda di masa yang akan datang. Berita negatif lain yang sering terjadi mereka telah berani melakukan kekerasan terhadap teman-temannya.

Dengan melihat peristiwa-peristiwa dan kasus di atas sudah saatnya para pendidik mendesain dan mengembangkan pendidikan karakter bagi anak usia dini agar mempunyai karakter yang baik (akhlak mulia), budi pekerti yang baik dengan meminimalisasi dampak negatif dari perkembangan jaman dan kemajuan teknologi. Guru anak usia dini (TK) diharapkan dapat mengintegrasikan pendidikan karakter dalam mentimulasi perkembangan sehingga anak usia dini (Tk) dapat menjadi warga negara yang baik sebagaimana harapan bangsa dan negara.

\section{A. Definisi dan Konsep Pendi- dikan Karakter}

Dalam Webster's Dictionary, pengertian kata karakter berarti "the aggragate features and traits that form the apparent individual nature of same person or thing; moral or ethical quality; qualities of honesty, courage, integrity; good reputation; an account of the cualities or peculiarities of a person or thing". Karakter merupakan totalitas dari ciri pribadi yang membentuk penampilan seseorang atau obyek tertentu. Ciri-ciri personal yang memiliki karakter terdiri dari kualitas moral dan etis; kualitas kejujuran, keberanian, integritas, reputasi yang baik; semua nilai tersebut di atas merupakan sebuah kualitas yang melekat pada kekhasan personal individu. Sedang menurut Ensiklopedia Indonesia, karakter memiliki arti antara lain; keseluruhan dari perasaan dan kemauan yang tampak dari luar sebagai kebiasaan seseorang bereaksi terhadap dunia luar dan impian yang diidam-idamkan (Tan Giok Lie, 2007). Pen-gertian karakter dilihat dari sudut pendidikan, didefinisikan sebagai stuktur rohani yang terlihat dalam perbuatan, dan terbentuk oleh faktor bawaan dan pengaruh lingkungan. Karakter mengacu pada kehidupan moral dan etis seseorang untuk mengasihi Tuhan dan sesama, yaitu kebajikan moral untuk berbuat baik.

Pendidikan karakter mempunyai makna lebih tinggi dari pendidikan moral, karena bukan sekedar mengajarkan mana yang benar dan mana yang salah, tetapi lebih dari itu karena pendidikan karakter menanamkan kebiasaan tentang hal yang baik sehingga anak-anak menjadi faham tentang mana yang benar dan salah, serta mampu merasakan nilai yang baik dan mau dan mampu melakukannya.

Dalam kamus besar bahasa Indonesia, "karakter" di artikan sebagai sifat-sifat kejiwaan, akhlak, atau budi pekerti. Karakter juga dapat di artikan sebagai tabiat, yaitu perangai atau perbuatan yang selalu di lakukan atau 
kebiasaan. Suyanto (2009) mendefinisikan karakter sebagai cara berpikir dan berperilaku yang menjadi ciri khas tiap individu untuk hidup dan bekerja sama baik dalam lingkup keluarga, masyarakat, bangsa dan $\mathrm{Ne}$ gara. Anak yang berkarakter baik adalah anak yang bisa membuat keputusan dan siap mempertanggung jawabkan tiap akibat dari keputusan yang di buatnya.

Definisi karakter menurut Pritchard (1988) adalah sesuatu yang berkaitan dengan kebiasaan hidup individu yang bersifat menetap dan cenderung positif. Dalam pendidikan karakter (Lickhona:1992) menekankan pentingnya tiga komponen karakter yang baik (components of good character) moral knowing atau pengetahuan tentang moral, moral feeling atau perasaan tentang moral dan moral action atau perbuatan moral. Ketiga komponen ini penting dan di perlukan agar anak usia dini mampu memahami, merasakan, dan sekaligus melaksanakan nilai-nilai kebaikan.

Moral action atau tindakan moral ini merupakan hasil (autcome) dari dua komponen karakter lainnya. Agar memahami apa yang mendorong seseorang untuk berbuat baik / perbuatan yang baik (act morally) maka harus di lihat tiga aspek lain dari karakter yaitu kompetensi (competence), keinginan (will), dan kebiasaan (habit). Anak Usia Dini tidak akan dapat melakukan tindakan moral apabila ia tidak memiliki kompetensi sosial, berkeinginan dan terbiasa melakukannya. Tindakan moral merupakan sesuatu yang harus di biasakan pada diri anak sejak kecil sehingga menjadi bagian dari karakternya (Sjarkawi, 2006).

Morl Action yang dapat diamati adalah kemurahan hati, simpati, empati, sikap ramah, dan maniru. Kemurahan hati merupakan perilaku kesediaan untuk berbagi dengan anak lain, jika hal ini meningkat, maka perilaku mementingkan diri sendiri akan ber- kurang. Perilaku kemurahan hati sangat di sukai oleh lingkungan sehingga menghasilkan penerimaan sosial yang baik. Mengekspresikan simpati dengan berusaha menolong atau menghibur seseorang yang sedang bersedih bagi anak merupakan sesuatu yang sangat baik bagi pembentukan karakter. Empati merupakan kemampuan meletakkan diri sendiri dalam posisi orang lain serta menghayati pengalaman orang tersebut. Perasaan empati ini hanya akan berkembang jika anak telah dapat memahami ekspresi wajah orang lain atau maksud pembicaraan orang lain. Sikap ramah seorang anak ditunjukkan dengan membantu teman, menunjukkan kasih sayang kepada taman, dan seorang anak memperlihatkan sikap ramah dengan cara melakukan sesuatu bersama orang lain. Sedangkan anak-anak melakukan peniruan terhadap orang-orang yang diterima baik oleh lingkungan, dengan meniru anak-anak mendapat respon penerimaan kelompok terhadap diri mereka.

Karakter adalah sesuatu yang dipahatkan pada hati, sehingga menjadi tanda yang khas, karakter mengacu pada moralitas dalam kehidupan sehari-hari. Karakter bukan merupakan gejala sesaat, melainkan tindakan yang konsisten muncul baik secara batiniah dan rohaniah. Karakter semacam ini disebut sebagai karakter moral atau identitas moral. Karakter mengacu pada kebiasaan berpikir, berperasaan, bersikap, berbuat yang memberi bentuk tekstur dan motivasi kehidupan seseorang. Karakter bersifat jangka panjang dan konstan, berkaitan erat dengan pola tingkah laku, dan kecenderungan pribadi seseorang untuk berbuat sesuatu yang baik.

Karakter adalah serangkaian nilai yang operatif, nilai yang nyata sebagai aktualisasi dalam tindakan. Kemajuan karakter adalah pada saat suatu nilai berubah menjadi kebajikan. Kebajikan dan kemurahan adalah kecenderungan batiniah seseorang yang 
merespon berbagai situasi dengan cara diungkapkan dengan baik secara moral. Karakter selalu mengacu pada kebaikan yang terdiri dari tiga bagian yaitu mengetahui yang baik, menginginkan yang baik dan melakukan yang baik. Ketiga kebiasaan ini didasarkan pada kebiasaan pikiran, hati dan kehendak. Karakter sebagai sesuatu yang melekat pada personal yaitu totalitas ide, aspirasi, sikap yang terdapat pada individu dan telah mengkristal di dalam pikiran dan tindakan (Tan Giok Lie, 2007). Manusia hanya dapat mengamati karakter secara eksternal dan parsial, dari kebiasan, pola pikir, pola sikap, pola tindak atau pola merespon secara emosional dan pola dalam bertingkah laku. Manusia bisa salah dalam memberikan penilaian terhadap karakter individu, hanya individu itu sendirinya yang mengetahui siapa jati dirinya.

Menurut suyanto (2009) ada 9 pilar karakter yang berasal dari nilainilai luhur universal, yaitu :1) karakter cinta Tuhan dan segenap ciptaan-nya, 2) kemandirian dan tanggungjawab, 3) kejujuran/ amanah, deplomatis, 4) hormat dan santun, 5) dermawan, suka tolong-menolong dan gotong royong / kerjasama, 6) percaya diri dan pekerja keras, 7) kepemimpinan dan keadilan, 8) baik dan rendah hati, 9) toleransi, kedamaian, dan kesatuan.

Menurut zulham (2010) ada 5 karakter yang harus di kembangkan yaitu: 1) trustworthy: meliputi jujur, menepati janji, memiliki loyalitas tinggi, integritas pribadi (komitmen, disiplin, selalu ingin berprestasi), 2) menghormati orang lain: perilaku untuk mementingkan kepentingan umum di atas kepentingan pribadi, siap dengan perbedaan dan tidak merasa paling benar, 3) bertanggung jawab: merupakan gabungan dari perilaku yang dapat di pertanggung jawabkannya, segala hal yang dilakukan harus berani menanggung akibatnya, berpikir sebelum bertindak, 4) adil yang meliputi: sikap terbuka, tidak memihak, mau mendengarkan orang lain dan memiliki empati, 5) cinta dan perhatian yang meliputi: menunjukkan perilaku kebaikan, hidup dengan nilai-nilai kebenaran, berbagi kebahagiaan, bersedia menolong orang lain, tidak egois, tidak kasar dan sensitf terhadap perasaan orang lain.

\section{B. Langkah-langkah Pembentukan Karakter pada Anak Usia Dini.}

Pendidikan anak usia dini merupakan bentuk pendidikan yang fundamental dalam kehidupan seorang anak dan pendidikan pada masa ini sangat menentukan keberlangsungan anak itu sendiri juga bagi suatu bangsa. Tiga puluh tahun yang akan datang bangsa Indonesia akan sangat tergantung pada anak usia dini yang ada pada masa sekarang. Oleh karena itu, pendidikan karakter ini merupakan tahapan penting bagi perkembangan seorang anak, bahkan suatu hal yang fondamental bagi kesuksesan perkembangan pembentukan karakter selanjutnya. Oleh karena itu, seorang guru tidak boleh mengabaikan kehadiran anak usia dini demi kepentingan di masa depan bagi generasi penerus. Seorang guru dituntut untuk memahami karakteristik anak usia dini, arti pentingnnya belajar bagi anak usia dini, tujuan belajar bagi anak usia dini, dan kegiatan belajar bagi anak usia dini. Pembentukan karakter anak usia dini bisa dilakukan melalui kegiatan rutin, kegiatan terprogram, kegiatan spontan, dan keteladanan.

Pembentukan karakter anak usia dini dapat mengikuti suatu pola tertentu, yaitu suatu perilaku yang teratur, disiplin, dan baku (sesuai standar) artinya berbagai jenis dan pola perilaku tersebut dapat di kembangkan melalui penjadwalan secara terus menerus hingga perilaku yang diharapkan melekat pada anak secara kuat dan menjadi bagian dari perilaku positif yang 
dimilikinya. Penjadwalan yang terus menerus itu sering disebut sebagai kegiatan rutin. Kegiatan ini juga sering kali disebut sebagai kegiatan pembiasaan karena memang sasaran dari kegiatan ini adalah untuk membiasakan perilaku tertentu yang dianggap mendasar dan penting bagi pola kehidupan anak saat ini maupun ketika anak itu dewasa.

Pembentukan karakter melalui kegiatan terprogram maksudnya adalah kegiatan yang menjadi agenda dan di rancang dalam silabus guru,baik untukjangka waktu yang pendek maupun jangka waktu yang panjang, yaitu untuk satu hari, satu minggu, satu bulan atau satu semester. Pembentukan karakter melalui kegiatan spontan dengan tujuan untuk lebih meningkatkan apresiasi anak terhadap nilai-nilai yang baik yang muncul berdasarkan kejadian nyata, dan muncul saat itu. Pembentukan karakter melalui kegiatan keteladanan atau contoh-contoh dengan maksud untuk mengarahkan anak pada berbagai contoh pola perilaku yang dapat di terima oleh masyarakat, yaitu dengan cara menampilkannya langsung di hadapan atau dalam kehidupan bersama anak.

Slamet Suyanto (2005) mengatakan bahwa pendidikan anak usia dini sebagai suatu upaya pembinaan yang ditujukan kepada anak usia dini yang dilakukan melalui pemberian rangsangan pendidikan untuk membantu pertumbuhan dan perkembangan jasmani dan rohani agar anak memiliki kesiapan dalam memasuki pendidikan dasar dan kehidupan tahap selanjutnya. Sedang prinsip-prinsip dalam proses belajar mengajar antara lain; Appropriate yaitu pembelajaran yang disesuaikan dengan tumbuh kembang jiwa anak, esensi bermain, holistik atau menyeluruh, terpadu atau integrated, bermakna, long life skills dan fleksibel.

Anak usia dini mengalami perkembangan fisik dan motorik, tak kecuali perkembangan kepribadian, watak, emosional, intelektual, bahasa, budi pekerti, dan moralnya yang tumbuh dengan pesat. Oleh karena itu jika menghendaki bangsa yang cerdas, dan berbudi pekerti luhur (bermoral baik) pendidikan harus dimulai sejak masa kanak-kanak.

Pendidikan moral memerlukan keterlibatan semua aspek kehidupan manusia, sehingga tidak cocok hanya menekankan pada aspek kognitif saja, hal ini dapat membunuh karakter anak. Namun pendikan moral bagi anak usia dini harus disesuikan dengan perkembangan jiwa anak, mengembangkan seluruh aspek kehidupan manusia; intelektual, karakter, estetika, dan fisik dan dalam koridor pembelajaran moral yang menyenangkan (Bobbi DePorter \& Mike Hernacki, 2003).

Dalam usaha mentransfer karakter (watak) dapat digunakan pendekatan dan metode pembelajaran yang tepat sesuai dengan tumbuh kembang jiwa anak. Menurut Habibah (Habibah, 2007: 1) dalam sosialisasi pendidikan moral dapat digunakan pendekatan indoktrinasi, klasifikasi nilai, keteladanan, dan perilaku guru. Keempat pendekatan tersebut di atas diharapkan dapat diterapkan sesuai dengan situasi kondisi serta dilakukan secara holistik sehingga tidak akan terjadi tumpang tindih. Pendekatan di atas juga diharapkan guru mengetahui karakteristik siswa maupun kondisi kelas, dan seorang guru harus memiliki kemampuan untuk mengimplementasikan psikologi pendidikan sehingga kelas kondusif untuk pembelajaran moral.

Pendekatan indoktrinasi dengan cara memberi hadiah atau hukuman, peringatan, dan pengendalian fisik. Sedang pendekatan klasifikasi nilai, dengan cara penalaran dan ketrampilan. Pendekatan keteladanan dengan cara disiplin, tanggung jawab, empati, dan pendekatan pembiasaan dengan 
cara perilaku seperti berdoa, berterima kasih. Pendekatan habitus diharapkan dapat merubah perilaku moral (Ambarwati, 2007).

\section{Pendidikan Karakter Anak Usia Dini}

Istilah pendidikan berasal dari kata paedagogi, dalam bahasa Yunani pae artinya anak dan ego artinya aku membimbing. Secara harafiah pendidikan berarti aku membimbing anak, sedang tugas pembimbing adalah membimbing anak agar menjadi dewasa. Secara singkat Driyarkara yang dikutip oleh Istiqomah (2003) mengatakan bahwa pendidikan adalah suatu usaha secara sadar yang dilakukan oleh pendidik melalui bimbingan atau pengajaran dan latihan untuk membantu peserta didik mengalami proses pemanusiaan diri ke arah tercapainya pribadi dewasa, susila dan dinamis.

Dalam mensosialisasikan nilai karakter perlu adanya komitmen para elit politik, tokoh masyarakat, guru, stakeholders pendidikan moral, dan seluruh masyarakat. Sosialisasi Pendidikan moral harus memperhatikan prinsip-prinsip antara lain:

"Pendidikan karakter adalah suatu proses, pendekatan yang digunakan secara komprehensif, pendidikan ini hendaknya dilakukan secara kondusif baik di lingkungan sekolah, rumah dan masyarakat, semua partisan dan komunitas terlibat di dalamnya. Sosialisasi pendidikan karakter perlu diadakan bagi kepala sekolah, guru-guru, muridmurid, orang tua murid, dan komunitas pemimpin yang merupakan esensial utama. Perlu perhatian terhadap latar belakang murid yang terlibat dalam proses kehidupan karakter. Perhatian pendidikan karakter harus berlangsung cukup lama (terus menerus), dan pembelajaran karakter harus diintegrasikan dalam kurikulum secara praksis di sekolah dan masyarakat (Setyo Raharjo, 2005).
Pendidikan karakter direncanakan secara matang oleh stakeholders, sebagai think-tank, baik para pakar karakter (akhlak) seperti rohaniawan (tokoh agama), pemimpin non formal (tokoh masyarakat), kepala sekolah, guru-guru, orang tua murid. Pendidikan karakter ini harus memperhatikan nilai-nilai secara holistik dan uiniversal. Keberhasilan pendidikan karakter dengan keluaran menghasilkan peserta didik yang memiliki kompetensi personal dan kompetensi sosial yang memiliki moral luhur dan dinamis sehingga menghasilkan warga negara yang baik (good citizen).

Dalam mewujudkan kehidupan moral bagi anak usia dini perlu strategi perjuangan secara struktural dan kultural secara bersama-sama. Strategi struktural dalam arti politis, perbaikan struktural ini merupakan sarana yang paling efektif adalah melalui kurikulum pendidikan anak usia dini $\mathrm{Me}$ lalaui lembaga pendidikan formal aspirasi masyarakat tentang karakter dapat disalurkan, dan nilai-nilai moral dapat diperjuangkan sebagai masukan dari masyarakat kepada pemerintah khsusnya Depdikbud. Input dari masyarakt kepada pemerintah akan dijabarkan dalam bentuk kebijaksanaan atau undang-undang yang mewajibkan dilaksanakannya karakter bagi anak-anak usia dini yang didukung dana dari pemerintah. Sebagaimana dikatakan oleh Gubernur DIY Sri Sultan Hamengkubuwono X meminta agar Pendidikan karakter dimasukkan dalam muatan lokal dan didanai oleh Pemerintah. Hal ini berkaitan erat dengan semakin merosotnya kehidupan moral terutama di kalangan anak muda (Kompas, 15 Maret 2007: I). Sementara secara kultural memerlukan perjuangan yang panjang. Perjuangan membangun mentalitas bangsa yang berbasis nilai-nilai moral pembentuk karakter melalui penghormatan kepada orang tua dan bersumber dari nilai moral, harus diawali dari 
individu yang mengutamakan kehidupan, menjunjung nilai-nilai moral, disemaikan dari lingkungan keluarga, lingkungan sekolahan dan masyarakat luas.

Dalam mensosialisasikan nilai-nilai karakter diperlukan guru, pejuang moral yang tidak pernah gentar, putus asa atau frustasi meskipun rintangan, halangan, lingkungan tidak kondusif, dan harus berhadapan dengan keadaan distruktif. Dengan tidak jemujemunya meneriakkan sosialisasi pendidikan karakter (akhlak mulia) untuk mewujudkan nilai karakter yang baik secara universal yang menghargai orang lain.

Guru harus bersedia bersinergis dengan orang tua anak didik untuk mewujudkan kehidupan karakter yang baik dengan menggunakan konsep gold three angle yaitu kerjasama antara perguruan tinggi, pemerintah dan penyandang dana. Perguruan tinggi mengadakan $\mathrm{R}$ dan $\mathrm{D}$ (researth \& development) dalam bidang pendidikan karakter yang telah diuji cobakan dan berhasil. Depdikbud termasuk Pejabat Kanwil Depdikbud memberi good will (kemudahan) melalui peraturan pemerintah dalam mensosialisasikan nilai-nilai karakter. Penyandang dana bisa dari grand (hadiah) atau donatur, hibah untuk mendanai riset dan sosialisasi nilai moral sehingga pendidikan moral bisa berjalan dengan baik seperti harapan.

Hasil penelitian perguruan tinggi tentang karakter diharapkan menambah alternatif pemerintah, yang dapat dipilih sebelum menentukan kebijakan dilaksanakan, selain itu tenaga dosen bersama mahasiswa dapat mendampingi masyarakat, sehingga perguruan tinggi dapat menjadi solusi dalam memecahkan memecahkan persoalan karakter. Dalam mengimplemtasikannya setiap lembaga dan personal bisa bersinergis dan tidak saling menyalahkan, pakar-pakar perguruan tinggi (khususnya pakar moral pakar akhlak) dapat memberi masukan pada pemerintah dan sekaligus terjun langsung ke masyarakat dengan langkah kongkrit untuk memperbaiki karakter peserta didik (Victor Purba, Kompas, Kamis, 22 Maret 2007).

J adi nilai karakter dibawa seorang guru yang meyakini kebenaran karakter sebagai ideologi ideal dan harus ditanamkan pada setiap hati (personal, individu) khsusnya anak usia dini agar suatu hari nanti kehidupan bangsa yang menjunjung nilai-nilai moral atau akhlak mulia (karaakter) dapat terwujud.

Dengan adanya benih nilai-nilai, nilai karakter yang sudah disemaikan dalam keluarga, diajarkan di sekolah oleh guru dan masyarakat diharapkan setiap personal dapat mempraktikkan nilai karakter baik dalam totalitas kehidupan bermasyarakat dan berbangsa. Modal nilai karakter yang sudah ada dalam personal merupakan lahan yang subur bagi anak-anak usia dini untuk mewujudkan kehidupan bersama dalam mewujudkan masyarakat yang ideal. Terlebih lagi dalam pembelajaran dan sosialisasi pendidikan moral dapat dimanfaatkan konsep learning to do, learning to be, learning to know, learning to live together.

Dalam usaha untuk mewujudkan masyarakat yang bermoral dapat digunakan konsep "Ingarso sung tuladho, Ing madyo mangun karso, Tut wuri handayani" Konsep pendidikan moral bagi anak usia dini di atas tidak hanya sebagai wacana tetapi harus diaktualisasikan ke dalam kehidupan nyata, sehingga pendidikan karakter (akhlak mulia) bisa mewujudkan masyarakat ideal seperti yang dicita-citakan.

\section{Penutup}

Pendidikan karakter akan berhasil apabila, guru memberi stimulus agar anak didik memberi respon sesuai dengan keinginan pendidik, dan dengan stimulus, respon itu anak didik 
diberi classical conditioning untuk menciptakan kondisi belajar yang lebih kondusif. Agar tujuan pendidikan karakter dapat tercapai, guru dapat merancang kegiatan dengan pendekatan rutin, terprogram, spontan maupun teladan. Proses stimulus dan respon dalam pendidikan karakter harus diberikan terus menerus dan terprogram, sehingga anak usia dini akan memiliki habitus (pendidikan yang merubah perilaku sehingga memiliki karakter baik) dalam mewujudkan manusia Indonesia yang berakhlak mulia.

Dalam melaksanakan pendidikan bermoral untuk mewujudkan anak usia dini yang ideal, pendidikan harus mampu mengembangkan kapasitas anak usia dini untuk membuat mereka sadar akan keberadaannya di dunia ini. Prinsip humanisme harus dijunjung secara otentik, bukan humanitarian. Prinsip humanisme yang ada dalam UU Sisdiknas adalah untuk mencapai manusia bermoral, bermartabat, berbudi pekerti luhur dan berkarakter atau berakhlak mulia.

Pendidikan karakter diharapkan dapat menghasilkan generasi penerus bangsa yang memiliki kompetensi personal dan sosial sehingga menjadi warga negara yang baik (good care atau good citizen) dengan ciri-cirinya antara lain: berani mengambil sikap positif untuk menegakkan normanorma sosial, aturan hukum dan nilainilai akhlak mulia atau berkarakter baik, demi masa depan bangsa yang mengedepankan nilai-nilai kebebasan, persamaan, persaudaraan, kesatuan, kebangsaan, kebhinekaan, multikultural, nasionalisme, demokrasi dan demokratisasi yang bersumber pada nilai budi pekerti dan moral bangsa.

Arah kebijaksanaan pendidikan karakter adalah untuk mewujudkan masyarakat sipil dengan parameter masyarakat lebih baik; demokratis, anti kekerasan, berbudi pekerti luhur, bermoral; masyarakat mendapat porsi partisipasi lebih luas, serta adanya landasan kepastian hukum, mengedepankan nilai-nilai egalitarian, nilai keadilan, menghargai HAM, penegakan hukum, menghargai perbedaan SARA dalam kesatuan bangsa. Menjunjung tinggi nilai-nilai religius dengan dilandasi pengamalan nilai-nilai moral Pancasila, yang diaktualisasikan baik secara obyektif dan subyektif sebagai paradigmanya. Pendidikan karakter harus menjadi bagian hidup dalam kehidupan sehari-hari akan sangat mendukung suasana yang kondusif untuk pelaksanaan pendidikan karakter mewujudkan Indonesia baru yang lebih ideal (Beautiful Cauntry artinya negeri yang indah, tanpa kekerasan, dan masyarakatnya hidup dalam kedamaian, gemah ripah loh jinawi, tata terntrem karta raharjo, dalam koridor Civil Society.

Diberikannya pendidikan karakter pada anak usia dini merupakan salah satu alternatif solusi penyelesaian untuk mengantisipasi kenakalan anak, kekerasan terhadap teman, pembalakan. Dengan tersosialisasikan pendidikan karakter diharapkan peserta didik dapat memahami, menganalisis, menjawab masalah-masalah yang dihadapi bangsa, dan dapat membangun kehidupan budi pekerti luhur dan moral bangsa secara berkesinambungan, konsisten yang bersumber pada nilai-nilai budi pekerti dan karakter bangsa sehingga cita-cita bangsa dan tujuan nasional bisa tercapai.

\section{Daftar Pustaka}

Ambarwati, dkk. Pendekatan dan Metode Pengembangan Moral Anak Usia Dini. Yogyakarta; FIP UNY. (makalah).

DePorter, Bobbi \& Mike Hernacki. 2003. Quantum Learning. J akarta. 
Dirjen PLS Depdiknas dengan UNY, 2007. Panduan Seminar dan Lokakarya Nasonal Pendidikan Anak Ussia Dini (PAUD) Peningkatan PAUD Berbasis Keluarga dalam Membangun Karakter Bangsa. Yogyakarta; FIP UNY.

Habibah, dkk. 2007. Metode Pengembangan Moral Anak Pra Sekolah. Yogyakarta: FIP UNY. (makalah).

Hartati, Sofia. 2005. Perekembangan Belajar Pada Anak Usia Dini. Jakarta: Departemen Pendidikan Nasional Dirjendikti Direktorat Pembinaan Tenaga Pendidikan dan Ketenagaan Perguruan Tinggi.

Hendrowibowo, 1. 2007. "Pendidikan Moral", Majalah Dinamika, FIP.

Istanto, Budi. 2007. Pentingnya Pendidikan Moral Bagi Generasi Penerus. Yogyakarta: FIP. UNY.

Lie, Tan Giok. 2007. Pendidikan Dini: Pembentukan Karakter Individu. Bandung: STT INTI.

Parjono. 2005. Pendidikan Nilai-nilai Moral . Yogyakarta: MKU, UNY.

Said, Umar. 2007. Google Pendidikan Moral.

Suyanto, Slamet. 2005. Konsep Dasar Pendidikan Anak Usia Dini. J akarta: Depdikbud, Dirjen Dikti. Direktorat Pembinaan Tenaga Pendidikan dan Pergruan Tinggi.

Pembelajaran Anak Usia Dini", Disampaikan pada Saresehan Pengembangan Pembelajaran di SD dan TK J urusan Pendidikan
Pra Sekolah dan Sekolah Dasar FIP. Puslit PAUD UNY.

Suyanto.2009 urgensi pendidikan karakter.http:// www.mandikdas men.depdiknas.go.id/web/pages/ urgensi.html.Diunduh pada april 2012.

Toufiqoh, Romi. 2007. Pentingnya Pendidikan Moral, Yogyakarta: FBS, UNY.

Wilkinson, Bruce H. 1994. Teaching With Style. Temukan Apa yang murid Anda ingini. Buletin PADU .2006.Pemberdayaan masyarakat dan keluarga.

Zulhan,Najib. 2010. Pendidikan Berbasis Karakter. Surabaya: J ePe Press Media Utama.

\section{Surat Kabar}

Sri Sultan Hamengkubuwono X, "Budi Pekerti Masuk Muatan Lokal", Kompas, 15 Maret 2007. 